\title{
Rancang Bangun Sistem Informasi Company Profile dan Monitoring Calon Pelamar Pada Perusahaan Berbasis Web (Studi Kasus : PT.Faros Bakti Utama Persada)
}

\author{
Asep Samsul Bakhri ${ }^{1}$, Anggi Elanda ${ }^{2}$, Eka Rahmawati ${ }^{3}$ \\ ${ }^{1,2,3}$ Teknik Informatika, STMIK Rosma, Karawang \\ E-mail: asep.bahri@dosen.rosma.ac.id
}

\begin{abstract}
The company profile information system is a way for companies to introduce the company to the general public and provide information about what fields the company is currently working on. In addition, the application for recruiting prospective applicants will be very useful for companies or for prospective applicants. This can minimize costs, especially for prospective applicants. Based on these problems, we need a system that can help make it easier for companies to introduce their companies, as well as make it easier for companies to monitor the process of new prospective applicants, and reduce expenses for prospective applicants in sending their application files. The method used to design this system is waterfall. While the data collection methods used in this research are literature studies, interviews, and observations. The results of this study are a company profile information system and monitoring of prospective applicants on web-based companies which are expected to help the problems that are being experienced by companies and prospective applicants. With this application, companies can introduce their company as well as simplify the filing process for prospective applicants. In addition, prospective applicants do not have to spend money to send their application files to the company.
\end{abstract}

Keywords: Company profile, Information System, Waterfall, Web

\begin{abstract}
Abstrak
Sistem informasi company profile merupakan cara agar perusahaan dapat memperkenalkan perusahaan pada khalayak umum serta memberikan informasi mengenai bidang apa yang tengah dijalani oleh perusahaan. Selain itu, aplikasi perekrutan calon pelamarpun akan sangat berguna bagi perusahaan ataupun bagi calon pelamar. Hal tersebut dapat meminimalisir adanya pengeluaran biaya, terutama bagi calon pelamar. Berdasarkan permasalahan tersebut, maka dibutuhkan sebuah sistem yang dapat membantu dalam mempermudah perusahaan memperkenalkan perusahaannya, sekaligus mempermudah perusahaan dalam proses monitoring calon pelamar baru, serta meringankan biaya pengeluaran bagi calon pelamar dalam mengirim berkas lamarannya. Metode yang digunakan untuk merancang sistem ini adalah waterfall. Sedangkan metode pengumpulan data yang digunakan dalam penelitian ini yaitu studi literratur, wawancara, dan observasi. Hasil penelitian ini adalah sebuah Sistem Informasi company profile dan monitoring calon pelamar pada perusahaan berbasis web yang diharapkan dapat membantu permasalahan yang tengah dialami oleh perusahaan maupun calon pelamar. Dengan adanya aplikasi ini, perusahaan dapat memperkenalkan perusahaannya sekaligus mempermudah dalam proses pemberkasan calon pelamar. Selain itu, calon pelamar tidak harus mengeluarkan biaya untuk mengirimkan berkas lamarannya kepada perusahaan.
\end{abstract}

Kata Kunci: Company profile, Sistem Informasi, Waterfall, Web

\section{Article History :}

Received 20, Oktober, 2021

Revised 16, November, 2021

Accepted 17, November, 2021

\section{Corresponding Author:}

Nama Penulis, Asep Samsul Bakhri

Departemen, Teknik Informatika

Instansi, STMIK Rosma

Alamat. Jl. Kertabumi No. 62 Karawang

Email Penulis. asep.bahri@dosen.rosma.ac.id 


\section{Pendahuluan}

Perkembangan teknologi informasi yang semakin canggih seperti saat ini, segala aktivitas khususnya pada pemanfaatan media komunikasi serta informasi yang di inginkan telah dapat dipenuhi melalui hadirnya sistem informasi yang disesuaikan dengan kebutuhan penggunanya.[1] Semakin maraknya pemanfaatan teknologi informasi yang difasilitasi internet membawa dampak positif yang luar biasa bagi user/pengguna, individu atau perusahaan.[2] Perusahaan merupakan salah satu bentuk organisasi yang merasakan dampak dari perkembangan teknologi informasi.[3] Kini dengan era digitalisasi perusahaan dituntut untuk dapat beradaptasi dan mengimplementasikan teknologi dan sistem informasi dilingkungan kegiatan usahanya.

Oleh karenanya di dalam pelaksanaannya, perusahaan butuh sumber daya manusia yang memiliki keterampilan yang baik untuk menunjang proses kegiatan produksinya. Perusahaan skala menengah keatas tentunya membutuhkan pegawai yang memiliki kemampuan terukur sesuai dengan kriteria - kriteria tertentu dilingkup perusahaannya [4].

Dikutip dari Kompasiana.com, bahwa "Merekrut karyawan selama pandemi COVID-19 tentu lebih sulit, sehingga memaksa perusahaan untuk meningkatkan penggunaan teknologi baru untuk mencari karyawan". Penerimaan pegawai baru adalah tahap yang strategis dalam mengidentifikasikan calon pelamar yang tepat.[5] Tujuan dari proses penerimaan pegawai adalah untuk mendapatkan orang yang tepat pada penempatan yang tepat sesuai bidang keahlian/kemampuannya di organisasi atau perusahaan [6].

PT. Faros Bakti Utama Persada merupakan salah satu perusahaan yang bergerak dibidang penyediaan jasa tenaga kerja untuk ditempatkan diperusahaan - perusahaan rekanannya. Perusahaan ini merupakan salah satu perusahaan yang tergabung didalam asosiasi Jasa Outsourcing dimana aturan serta tata cara pelaksanaannya merujuk kepada ketentuan yang berlaku sebagaimana tercantum pada Pasal 64 UU Ketenagakerjaan.

Sistem informasi merupakan suatu sistem di dalam organisasi yang mempertemukan kebutuhan pengolahan transaksi harian, mendukung operasi, bersifat manajerial dan kegiatan strategi dari sebuah organisasi serta menyediakan pihak luar tertentu dengan laporan-laporan yang di perlukan [7].

Sistem informasi yang dibutuhkan dalam perusahaan dapat berupa company profile berbasis web dengan maksud untuk mempermudah siapa saja dalam mengenal perusahaan tersebut. Company profile merupakan bentuk perkenalan profesional dari sebuah bisnis dengan tujuan untuk menginformasikan kepada orang-orang tentang keberadaan bisnis tersebut serta produk/jasa apa yang ditawarkan [8]. Sistem informasi akan lengkap jika ditambahkan sistem pendataan calon pegawai baru karena selain hemat waktu, sistem ini juga dapat menghemat biaya bagi perusahaan maupun calon pelamar.

Oleh karena itu, melihat dari latar belakang yang telah diuraikan diatas, penulis tertatik untuk merancang suatu sistem informasi monitoring calon pelamar pada Perusahaan Berbasis Web (Studi Kasus: PT.Faros Bakti Utama Persada). Melalui fasilitas sistem informasi ini, manfaat bagi calon pelamar dapat mendaftarkan secara online biodata pelamar serta persyaratan berkas berupa dokumen yang harus disertakan melalui fasilitas upload data dokumen yang tersedia pada sistem tersebut, sehingga dapat menghemat waktu dan biaya. Manfaat dari sisi perusahaan dapat melakukan seleksi dan melihat kesesuaian dokumen pelamar sebagai tahap awal berdasar kriteria berkas pendukung melalui 
sistem informasi di website penerimaan. Keuntungan lain juga dapat dirasakan oleh perusahaan, yaitu dengan adanya sistem ini perusahaan dapat memperkenalkan produknya kepada khalayak masyarakat, dengan begitu perusahaan dapat dikenal banyak orang akan mendatangkan banyak pengguna jasa atau produk dari perusahaan.

\section{Tinjauan Pustaka}

\subsection{Sistem Informasi}

Sistem Informasi merupakan cara tertentu untuk menyediakan informasi yang dibutuhkan oleh organisasi agar beroperasi dengan cara yang sukses dan untuk organisasi bisnis dengan cara yang menguntungkan. [9]

\subsection{Company Profile}

Company profile merupakan bentuk perkenalan profesional dari sebuah bisnis dengan tujuan utama untuk menginformasikan kepada orang-orang mengenai keberadaan bisnis tersebut serta produk/jasa yang ditawarkan.[10]

\subsection{Web}

Dalam Jurnal on Networking and Security, Jhonsen (2004) menuturkan bahwa "Web merupakan kumpulan dari halamanhalaman yang berhubungan dengan file-file lain yang saling terkait".[11]

\subsection{Waterfall}

Metode waterfall merupakan suatu proses berurutan, terus mengalir ke bawah (seperti air terjun) melewati fase-fase perencanaan, permodelan, implementasi, dan pengujian.

\subsection{HTML}

HTML adalah bahasa dasar pemrograman yang biasa dipakai untuk membuat halaman web yang dapat di akses dengan internet [12].

\subsection{PHP (Hypertext Processor)}

PHP (Hypertext Processor) adalah bahasa pemrograman server-siden scripting yang bersifat open source, yang mana script nantinya akan diproses di server [13].

\subsection{MySQL}

My Structure Query Language (MySQL) yaitu sebuah software database, yang merupakan tipe data relasional yang artinya MySQL penyimpanan datanya dalam bentuk tabel-tabel yang saling berhubungan. [14].

\section{Metode Penelitian}

Metode penelitian yang digunakan adalah Waterfall. Tahapan-tahapan dari Metode ini yaitu sebagai berikut.

\section{a. Requirement Gathering and Analysis}

Requirement gathering and analysis yaitu proses untuk pengumpulan kebutuhan secara lengkap, kemudian dianalis dan didefinisikan kebutuhan yang harus dipenuhi oleh program yang akan dibangun.

1) System Design

System Design yaitu tahap dimana pengembang akan menghasilkan gambaran dari sistem secara keseluruhan serta menentukan alur dari perangkat lunak hingga algoritma secara detail.

2) Implementasi/development

Implementasi/development yaitu tahapan dimana design sistem diubah menjadi kode-kode program. Kode program masih berupa modul-modul yang akan diintegrasikan menjadi sistem yang lengkap.

3) Integration \& Testing

Integration \& Testing yaitu tahap dilakukannya penggabungan modul-modul yang sudah dibuat dan dilakukan pengujian ini dilakukan untuk mengetahui apakah software yang dibuat telah sesuai dengan desainnya dan fungsi pada software terdapat kesalahan atau tidak.

4) Maintenance

Maintenance adalah instalasi serta proses perbaikan sistem sesuai yang disetujui. [15] 


\section{b. Metode Pengumpulan Data}

\section{1) Studi Literatur}

Studi literatur merupakan serangkaian kegiatan yang berhubungan dengan metode pengumpulan data pustaka, membaca dan mencatat, serta mengelola bahan penelitian dengan tujuan untuk menyelesaikan persoalan dengan mencari sumber-sumber penelitian yang pernah dibuat sebelumnya.

2) Wawancara

Wawancara merupakan teknik pengumpulan data secara langsung melalui tatap muka serta melakukan kegiatan tanyajawab dengan narasumber.

3) Observasi

Observasi

merupakan teknik pengumpulan data dengan cara terjun langsung ke lapangan untuk mengamati permasalahan yang tengah terjadi. Dalam penelitian ini, peneliti mengamati secara langsung dengan mengunjungi lokasi-lokasi yang dianggap perlu dalam penelitian ini, seperti mengunjungi PT.Faros Bakti Utama Persada untuk diamati [16].

\section{Hasil dan Pembahasan \\ 4.1.Sistem Yang Berjalan}

Sistem informasi company profile yang saat ini dimiliki oleh PT.Faros Bakti Utama Persada masih terbilang sederhana sehingga informasi mengenai perusahaanpun kurang lengkap. Selain itu, sistem pendataan calon pelamarpun masih menggunakan cara manual, yaitu pelamar yang harus mendatangi lokasi perusahaan dengan membawa berkas lamaran dan HRD yang harus mengecek secara manual berkas lamaran yang untuk memilih kelengkapan pelamar mana saja yang sesuai dengan persyaratan perusahaan yang membutuhkan pegawai baru, sedangkan berkas pelamar yang tidak sesuai dengan persyaratan akan menumpuk dan dibuang begitu saja.

Berikut ini merupakan tampilan flowchart sistem yang sedang berjalan di PT.Faros Bakto Utama Persada.

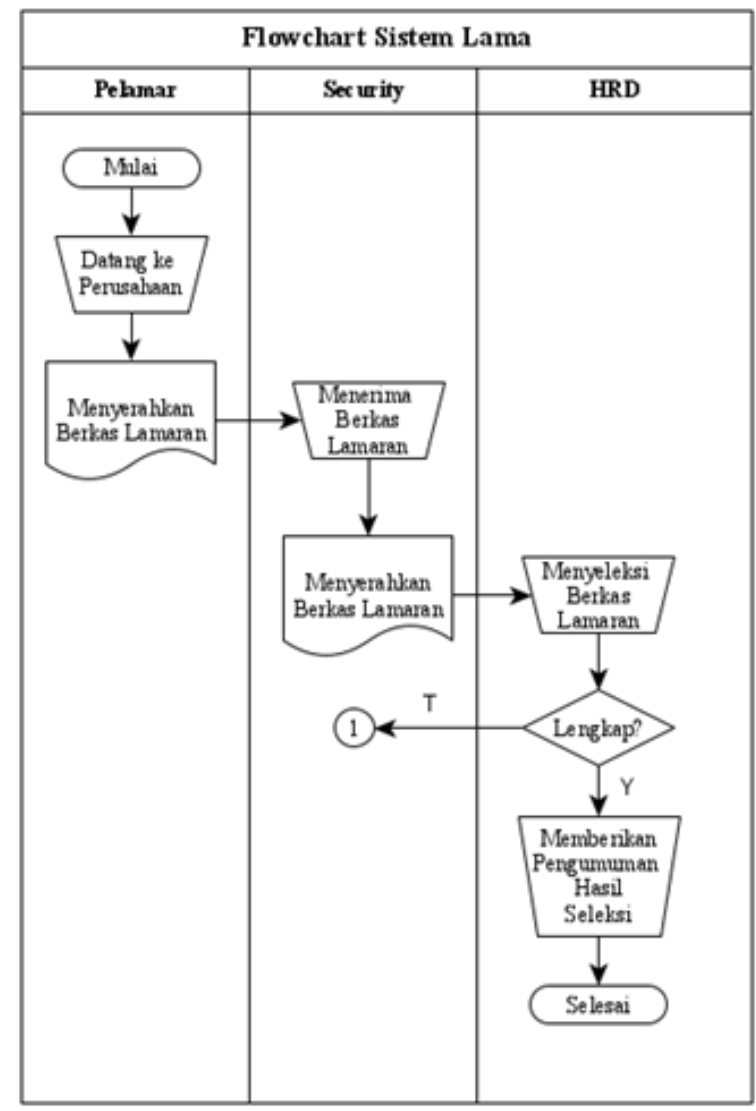

Gambar 1. Flowchart Sistem Lamar

Penjelasan :

a. Mulai

b. Calon pelamar yang ingin melamar pekerjaan bisa datang langsung untuk memberikan berkas lamaran ke bagian security PT.Faros Bakti Utama Persada.

c. Lalu bagian security menyerahkan lamaran tersebut ke pihak HRD.

d. HRD melakukan seleksi awal, dari setiap berkas yang masuk, memeriksa kelengkapan dan kesesuaian berkas sesuai dengan standar yang ada.

e. Jika lamaran tersebut sudah memenuhi syarat kelengkapan dokumen, maka HRD akan melakukan pemanggilan bagi pelamar untuk melakukan test selanjutnya, namun jika berkas belum lengkap maka pelamar tidak akan mendapat panggilan.

f. Selesai.

\subsection{Sistem Yang diusulkan}


Dalam penelitian ini, peneliti mengusulkan sistem infromasi baru yang dapat dilihat dari tabel flowchart berikut ini.

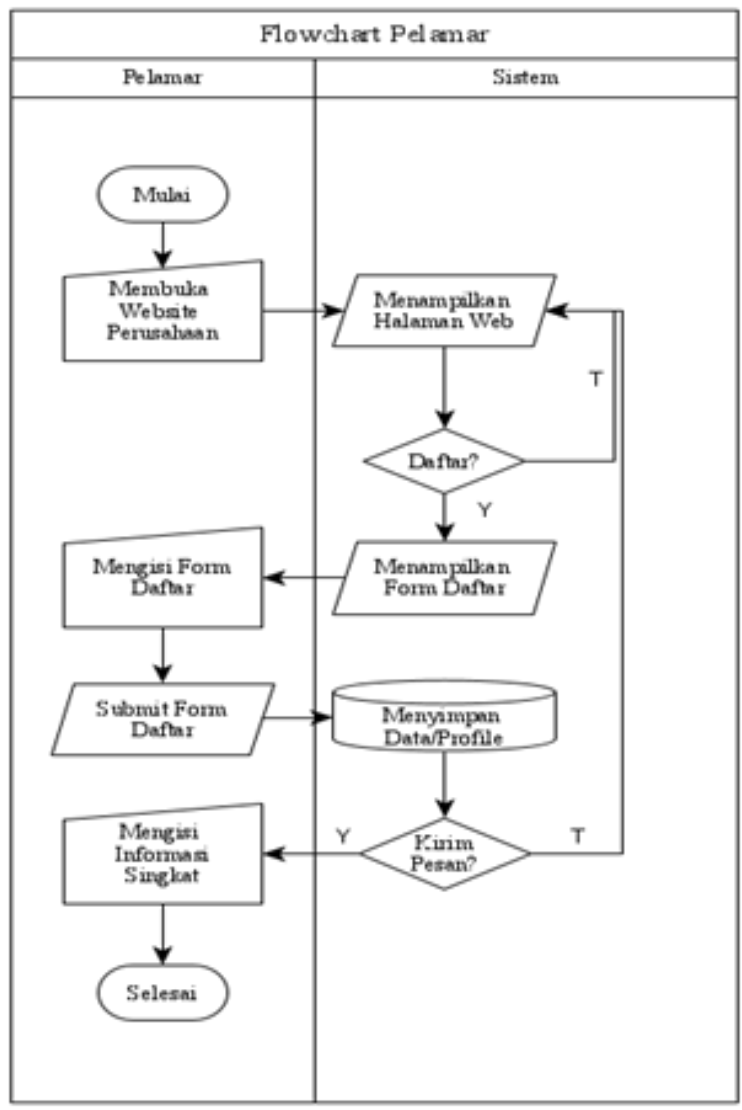

Gambar 2. Flowchart Sistem yang diusulkan

Penjelasan :

a. Mulai

b. Calon pelamar membuka website Company Profile PT.Faros Bakti Utama Persada.

c. Jika calon pelamar tertarik dan ingin melakukan pendaftaran, dapat melakukan pengisian formulir untuk mendaftarkan diri sebagai pelamar, melalui menu 'Kirim Lamaran', namun jika hanya ingin melihat infromasi mengenai perusahaan saja, maka tidak harus membuka halaman 'Kirim Lamaran' tersebut.

d. Pelamar tidak harus melakukan login, proses login hanya dapat diakses oleh admin perusahaan. e. Pelamar mengisi formulir secara online seperti nama, NIK, tempat tanggal lahir, alamat, no.telpon, email, dan lain-lain, serta memasukkan dokumen pendukung lainnya. Setelah itu simpan formulir lamaran.

f. Setelah itu sistem akan menyimpan data/profile pelamar.

g. Jika penyimpanan data pelamar sudah berhasil dilakukan, pelamar juga dapat mengisi informasi pemberitahuan singkat, melalui fasilitas pesan singkat/live chat yang tersedia.

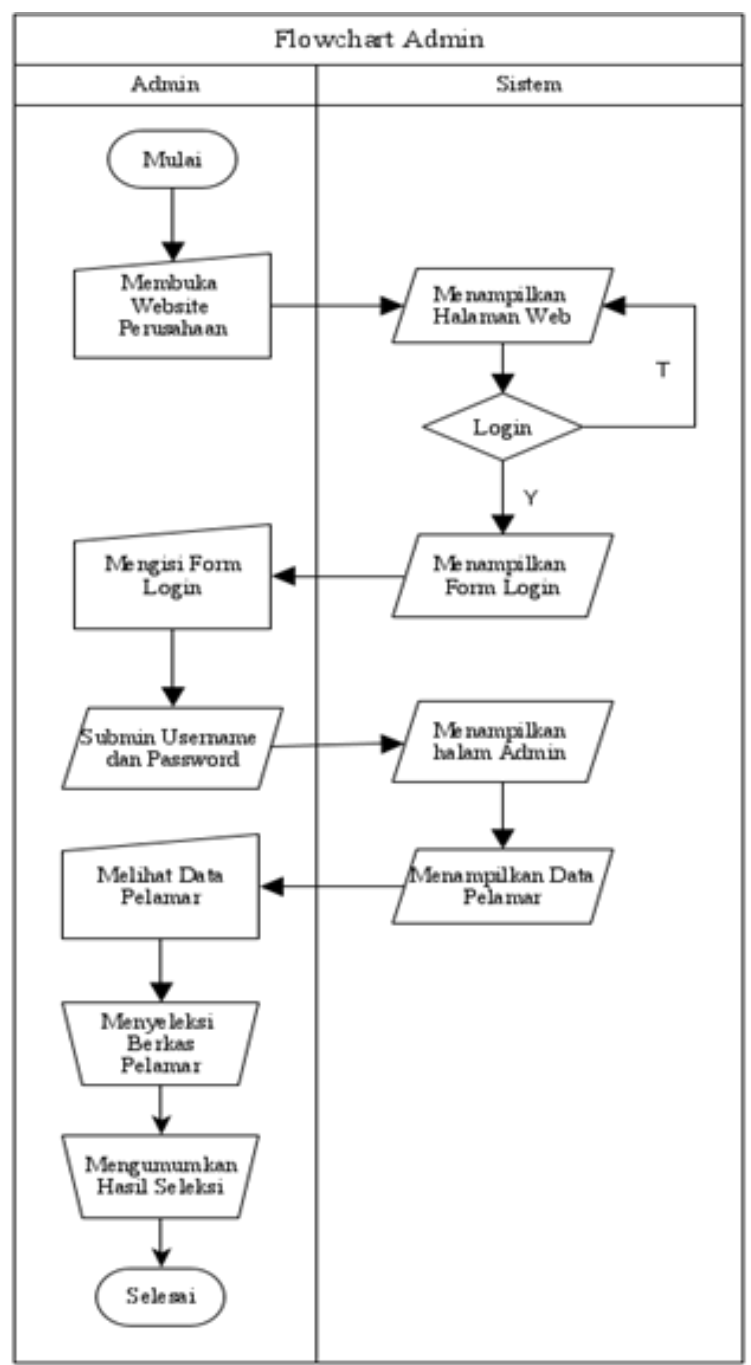

Gambar 3. Tabel Flowchart Sistem Admin

Penjelasan :

a. Mulai.

b. Admin melakukan Login 
c. Admin melihat data dokumen dari pelamar didaftar pelamar.

d. Lalu admin melakukan proses penyeleksian secara langsung terhadap berkas pelamar.

e. Setelah proses seleksi dokumen selesai dilakukan, maka admin dapat menentukan waktu untuk pemanggilan test dan tahapan seleksi selanjutnya.

f. Pelamar akan mendapatkan informasi lolos seleksi dan waktu keperusahaan melalui pesan telp atau email.

g. Selesai.

\subsection{Implementasi Sistem}

a. Halaman Dashboard

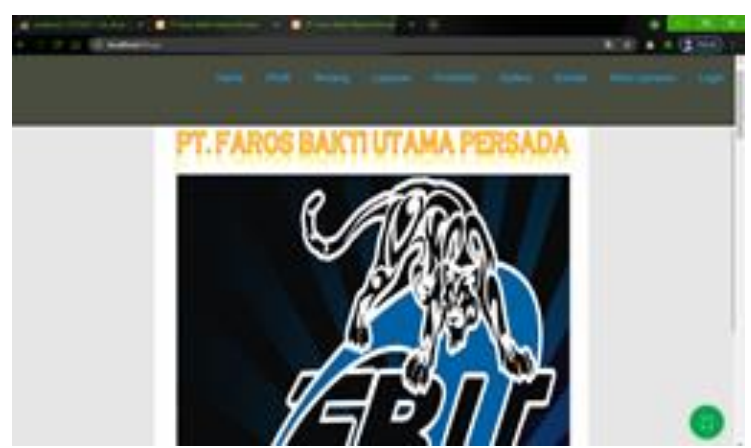

Gambar 3. Halaman Web

Berfungsi untuk menampilkan halaman utama sekaligus memberi menu halaman untuk dapat diakses oleh admin dan umum.

b. Halaman Informsi Profil Perusahaan
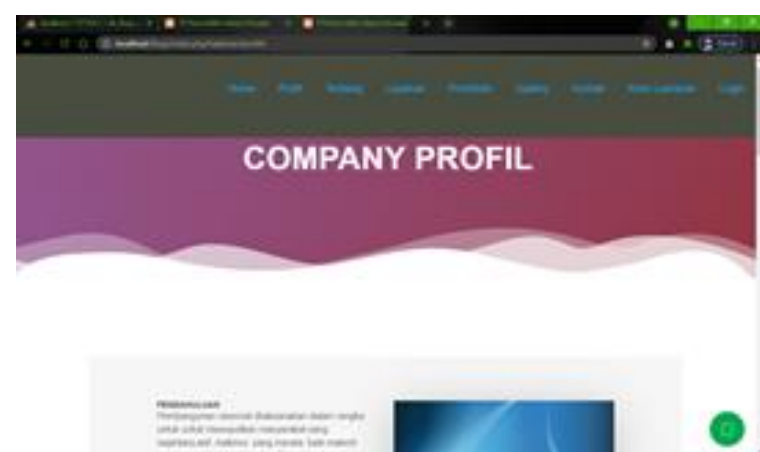

Gambar 4. Halaman Profil Perusahaan
Berfungsi untuk memberi informasi mengenai perusahaan, alamat perusahaan, serta informasi-informasi lainnya.

\section{c. Halaman Tentang}

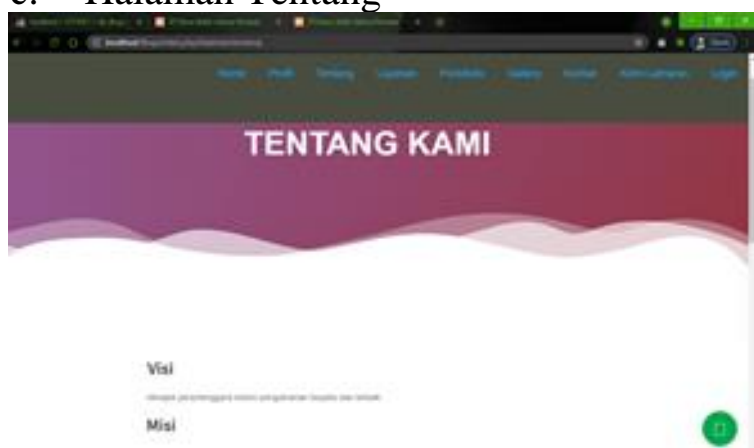

Gambar 5. Halaman Tentang

Berisi visi dan misi serta moto perusahaan.

d. Halaman Layanan

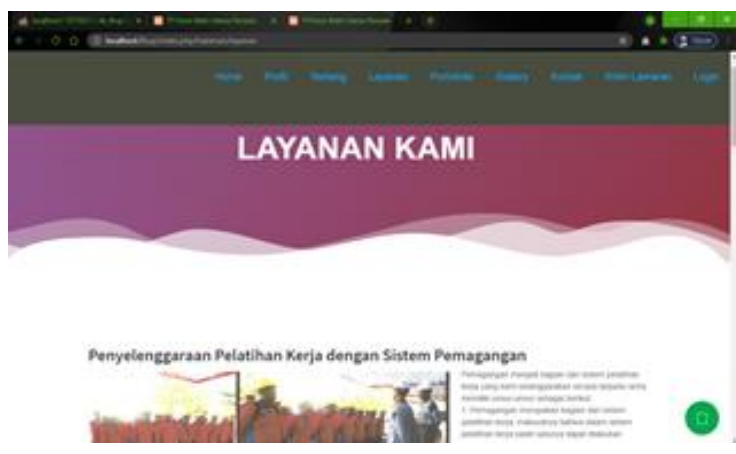

Gambar 6. Halaman Layanan

Halaman ini berisi informasi mengenai bidang apa yang tengah perusahaan jalani.

\section{e. Halaman Portofolio}
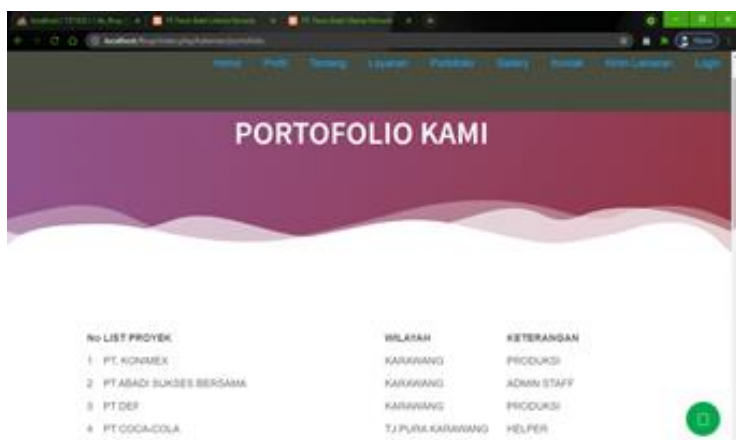

Gambar 7. Halaman Portofolio 
Berfungsi untuk memberikan informasi mengenai perusahaan apa saja yang bekerja sama dengan perusahaan.

\section{f. Halaman Galeri}

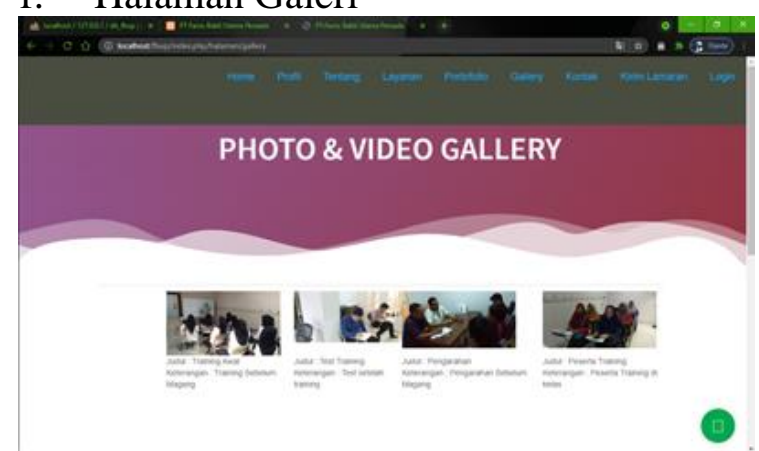

Gambar 8. Halaman Galeri

Berisi dokumentasi dari kegiatan yang biasa perusahaan lakukan.

g. Halaman Kontak

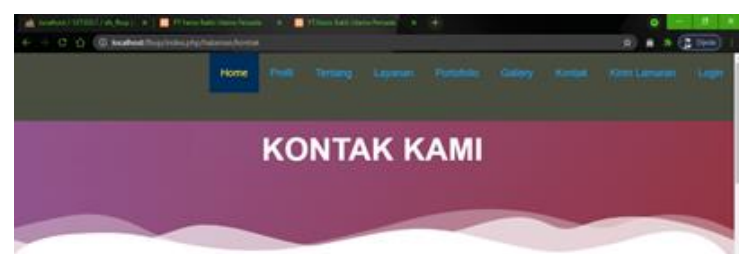

Gambar 9. Halaman Kontak

Berisi informasi kontak perusahaan, dimana di dalamnya terdapat code QR untuk dapat di scan oleh pengguna.

\section{h. Halaman Kirim Lamaran}

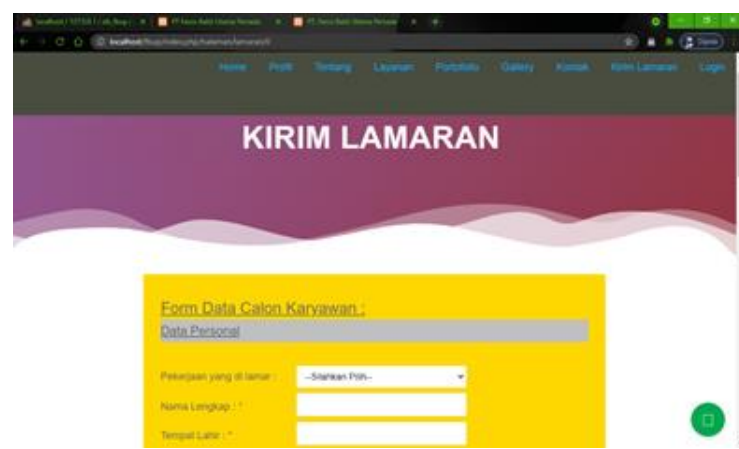

Gambar 10. Halaman Kirim Lamaran
Berisi formulir yang dapat diakses oleh calon pelamar untuk mengisi data diri dan berkas lainnya sebagai persyaratan lamaran.

\section{i. Halaman Login Admin}

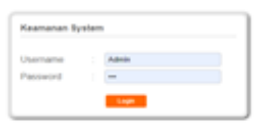

Gambar 11. Halaman Login

Berfungsi untuk membatasi akses masuk, dimana hanya admin/HRD saja yang dapat mengaksesnya.

\section{j. Halaman Home Admin}

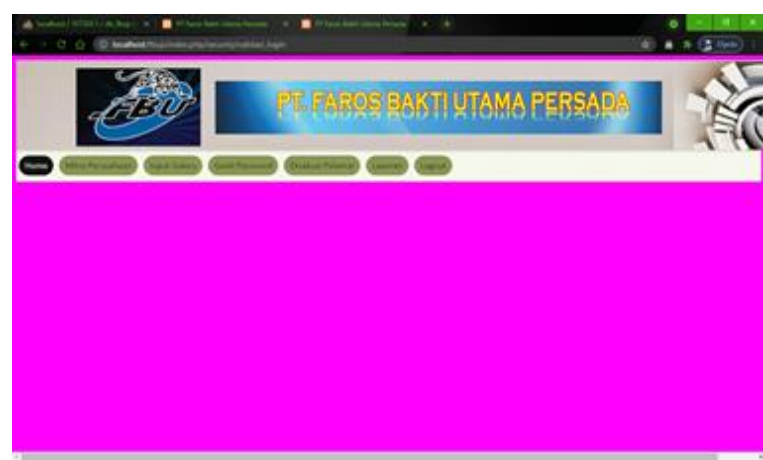

Gambar 12. Halaman Home Admin

Halaman home yang hanya bisa dilihat oleh admin.

\section{k. Halaman Mitra Perusahaan}

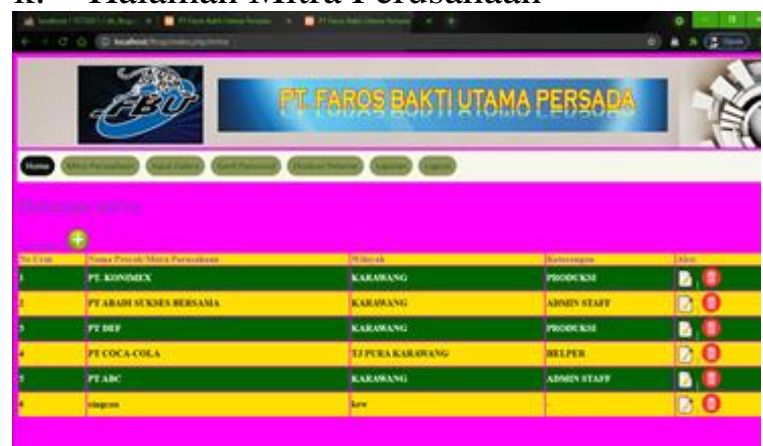

Gambar 13. Halaman Mitra Perusahaan

Jurnal Interkom: Jurnal Publikasi Ilmiah Bidang Teknologi Informasi dan Komunikasi

Volume 16 Nomor 03 Bulan Oktober - Tahun 2021 
Halaman untuk menambahkan atau menghapus daftar mitra perusahaan yang hanya dapat dilakukan oleh admin.

\section{Halaman Input Galeri}

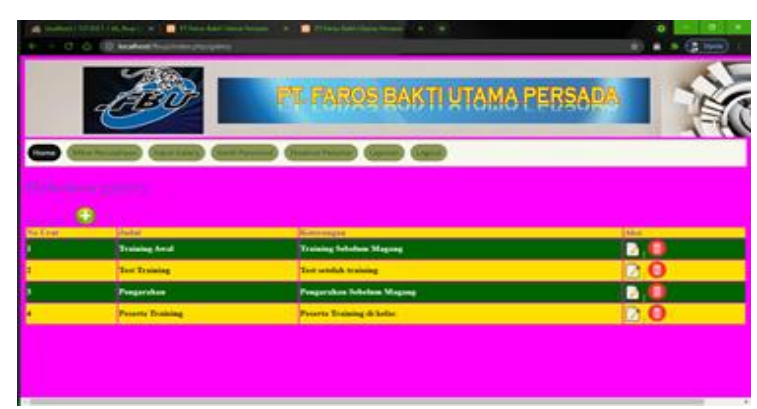

Gambar 14. Halaman Input Galeri

Halaman untuk menambahkan atau menghapus photo hasil dokumentasi, seperti photo kegiatan perusahaan. Halaman ini hanya dapat diakses oleh admin.

\section{m. Halaman Ganti Password}

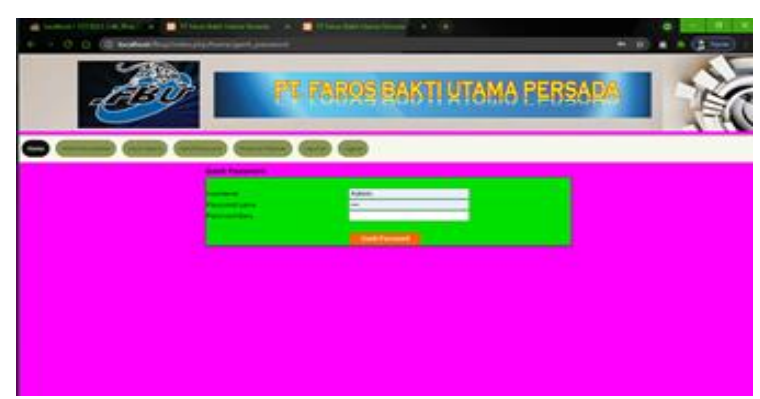

Gambar 15. Halaman Ganti Password

Halaman ini berfungsi untuk mengganti password admin.

\section{n. Halaman Eksekusi Pelamar}

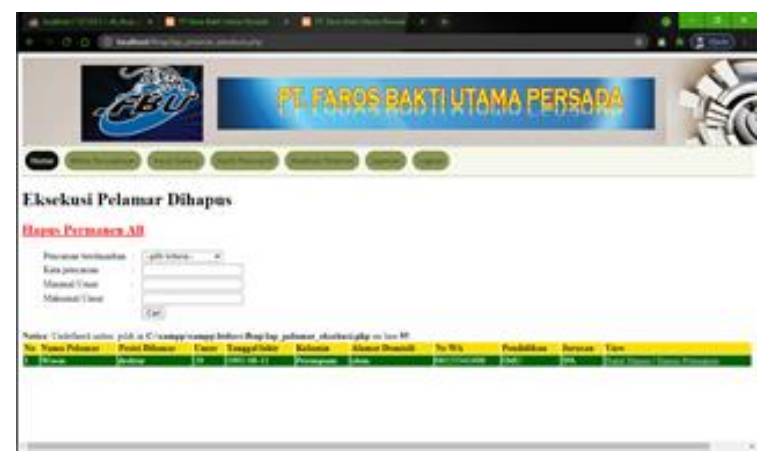

Gambar 16. Halaman Eksekusi Pelamar
Halaman ini berfungsi untuk menghapus daftar berkas calon pelamar yang tidak sudah dibutuhkan.

\section{o. Halaman Daftar Pelamar}

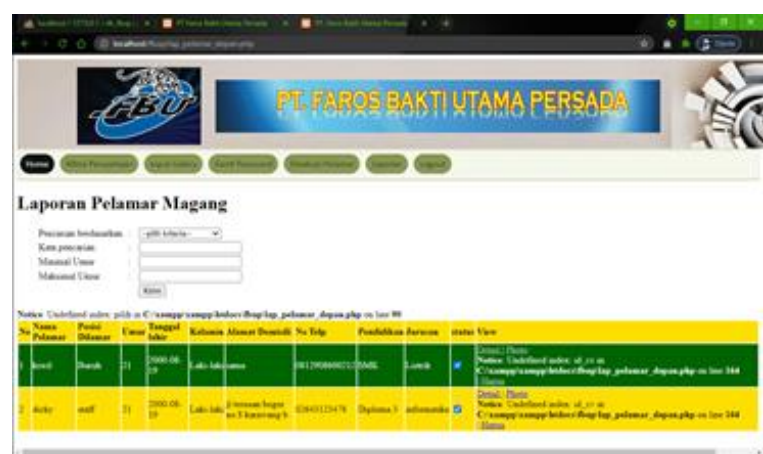

Gambar 17. Halaman Daftar Pelamar

Halaman untuk melihat daftar dari pelamar yang sudah mengisi formulir dengan benar.

\subsection{Pengujian Sistem}

Black box testing merupakan pengujian kualitas perangkat lunak yang berfokus pada fungsionalitas perangkat lunak. Pengujian black box testing bertujuan untuk menemukan fungsi yang tidak benar, kesalahan antarmuka, kesalahan pada struktur data, kesalahan perfomansi, kesalahan inisialisasi dan terminasi [17]. Pada Black box testing dilakukan pengujian yang didasarkan pada detail aplikasi seperti tampilan aplikasi, fungsi-fungsi yang ada didalam aplikasi, dan kesesuaian alur fungsi dengan bisnis proses yang dilakukan oleh customer. Hasil Black Box pengujian dapan dilihat pada tabel berikut ini.

Tabel 1. Hasil Pengujian Black Box

\begin{tabular}{|c|c|c|c|}
\hline No. & $\begin{array}{l}\text { Aktivitas } \\
\text { Pengujian }\end{array}$ & $\begin{array}{l}\text { Realisasi yang } \\
\text { Diharapkan }\end{array}$ & Hasil \\
\hline 1 & $\begin{array}{lr}\text { Masuk } & \text { ke } \\
\text { halaman } & \text { utama } \\
\text { web } & \\
\end{array}$ & $\begin{array}{l}\text { Halaman home } \\
\text { terbuka }\end{array}$ & Ya \\
\hline 2 & $\begin{array}{l}\text { Membuka } \\
\text { halaman 'Profil' } \\
\text { untuk } \\
\text { mengetahui }\end{array}$ & $\begin{array}{l}\text { Halaman 'Profil' } \\
\text { terbuka dan } \\
\text { Profile perusahaan } \\
\text { terdapat } \\
\text { didalamnya. }\end{array}$ & $\mathrm{Ya}$ \\
\hline
\end{tabular}

Jurnal Interkom: Jurnal Publikasi Ilmiah Bidang Teknologi Informasi dan Komunikasi

Volume 16 Nomor 03 Bulan Oktober - Tahun 2021 


\begin{tabular}{|c|c|c|c|}
\hline No. & $\begin{array}{l}\text { Aktivitas } \\
\text { Pengujian }\end{array}$ & $\begin{array}{l}\text { Realisasi yang } \\
\text { Diharapkan }\end{array}$ & Hasil \\
\hline & $\begin{array}{l}\text { profile } \\
\text { perusahaan. }\end{array}$ & & \\
\hline 3 & $\begin{array}{l}\text { Membuka } \\
\text { halaman } \\
\text { 'Tentang' untuk } \\
\text { mengetahui Visi, } \\
\text { Misi, dan Moto } \\
\text { perusahaan. }\end{array}$ & $\begin{array}{l}\text { Halaman } \\
\text { 'Tentang' terbuka } \\
\text { dan visi, misi, } \\
\text { serta } \\
\text { perusahaan } \\
\text { tertulis } \\
\text { didalamnya. }\end{array}$ & $\mathrm{Ya}$ \\
\hline 4 & $\begin{array}{l}\text { Membuka } \\
\text { halaman } \\
\text { 'Layanan', untuk } \\
\text { mengetahui } \\
\text { dalam bidang apa } \\
\text { perusahaan } \\
\text { berjalan. }\end{array}$ & $\begin{array}{l}\text { Halaman } \\
\text { 'Layanan' dapat } \\
\text { terbuka, dan berisi } \\
\text { informasi bidang } \\
\text { perusahaan. }\end{array}$ & $\mathrm{Ya}$ \\
\hline 5 & $\begin{array}{l}\text { Membuka } \\
\text { halaman } \\
\text { 'Portofolio'untu } \\
\text { k melihat daftar } \\
\text { perusahaan yang } \\
\text { bekerja sama } \\
\text { dengan } \\
\text { perusahaan ini. }\end{array}$ & $\begin{array}{l}\text { Halaman } \\
\text { 'Portofolio' } \\
\text { terbuka, berisi } \\
\text { daftar perusahaan } \\
\text { yang bekerja sama } \\
\text { dengan } \\
\text { perusahaan ini. }\end{array}$ & $\mathrm{Ya}$ \\
\hline 6 & $\begin{array}{l}\text { Membuka } \\
\text { halaman } \\
\text { 'Gallery' untuk } \\
\text { melihat } \\
\text { dokumentasi } \\
\text { kegiatan } \\
\text { perusahaan }\end{array}$ & $\begin{array}{l}\text { Halaman } \\
\text { 'Galerry' terbuka, } \\
\text { berisi beberapa } \\
\text { photo kegiatan } \\
\text { perusahaan. }\end{array}$ & Ya \\
\hline 7 & $\begin{array}{l}\text { Membukan } \\
\text { halaman } \\
\text { 'Kontak' untuk } \\
\text { melihat kontak } \\
\text { perusahaan. }\end{array}$ & $\begin{array}{l}\text { Halaman 'Kontak' } \\
\text { terbuka, terdapat } \\
\text { code QR untuk } \\
\text { dapat di scan dan } \\
\text { melihat dimana } \\
\text { lokasi perusahaan. }\end{array}$ & $\mathrm{Ya}$ \\
\hline 8 & $\begin{array}{lr}\text { Membuka } \\
\text { Halaman 'Kirim } \\
\text { Lamaran' untuk } \\
\text { mengisi biodata } \\
\text { dan r berkas } \\
\text { lamaran. }\end{array}$ & $\begin{array}{l}\text { Halaman 'Kirim } \\
\text { Lamaran' terbuka, } \\
\text { terdapat form } \\
\text { untuk mengisi } \\
\text { biodata dan } \\
\text { memasukkan } \\
\text { berkas tambahan } \\
\text { bagi pelamar. }\end{array}$ & $\mathrm{Ya}$ \\
\hline 9 & $\begin{array}{l}\text { Membuka } \\
\text { halaman 'Login' } \\
\text { untuk admin }\end{array}$ & $\begin{array}{l}\text { Halaman 'Login' } \\
\text { terbuka, hanya } \\
\text { admin yang dapat } \\
\text { mengakses } \\
\text { halaman ini. }\end{array}$ & $\mathrm{Ya}$ \\
\hline 10 & $\begin{array}{lr}\text { Masuk r } \\
\text { halaman 'Mitra' } \\
\text { untuk admin } \\
\text { menambah atau } \\
\text { menghapus } \\
\text { daftar mitra } \\
\text { perusahaan. }\end{array}$ & $\begin{array}{l}\text { Halaman 'Mitra' } \\
\text { dapat terbuka, dan } \\
\text { admin dapat } \\
\text { menambah atau } \\
\text { menghapus mitra } \\
\text { perusahaan pada } \\
\text { halaman tersebut. }\end{array}$ & $\mathrm{Ya}$ \\
\hline 11 & $\begin{array}{lr}\text { Masuk r } & \text { ke } \\
\text { halaman } & \text { 'Input } \\
\text { Galeri' untuk } & \text { menambahkan }\end{array}$ & $\begin{array}{lr}\text { Halaman } & \text { 'input } \\
\text { galeri' } & \text { dapat } \\
\text { terbuka, } & \text { dam } \\
\text { admin } & \text { dapat } \\
\end{array}$ & Ya \\
\hline
\end{tabular}

\begin{tabular}{|c|c|c|c|}
\hline No. & $\begin{array}{c}\text { Aktivitas } \\
\text { Pengujian } \\
\end{array}$ & $\begin{array}{c}\text { Realisasi yang } \\
\text { Diharapkan }\end{array}$ & Hasil \\
\hline & $\begin{array}{l}\text { atau mengahapus } \\
\text { photo pada } \\
\text { halaman galeri. }\end{array}$ & $\begin{array}{l}\text { menambah atau } \\
\text { menghapus photo } \\
\text { galeri. }\end{array}$ & \\
\hline 12 & $\begin{array}{l}\text { Masuk ke } \\
\text { halaman 'Ganti } \\
\text { password' untuk } \\
\text { admin mengganti } \\
\text { password login }\end{array}$ & $\begin{array}{lr}\text { Halaman } & \text { 'Ganti } \\
\text { password' } & \text { dapat } \\
\text { terbuka, } & \text { dan } \\
\text { admin } & \text { dapat } \\
\text { mengganti } & \\
\text { password } & \text { untuk } \\
\text { login. } & \\
\end{array}$ & $\mathrm{Ya}$ \\
\hline 13 & $\begin{array}{lr}\text { Masuk } & \text { ke } \\
\text { halaman } & \\
\text { 'Eksekusi } & \\
\text { Pelamar' } & \text { untuk } \\
\text { mencari } & \text { data } \\
\text { pelamar } & \text { seseuai } \\
\text { dengan kriteria } \\
\text { yang dicari. }\end{array}$ & $\begin{array}{l}\text { Halaman dapat } \\
\text { dibuka dan admin } \\
\text { dapat mencari data } \\
\text { pelamar pada } \\
\text { halaman tersebut. }\end{array}$ & $\mathrm{Ya}$ \\
\hline 14 & $\begin{array}{lr}\text { Masuk } & \text { ke } \\
\text { halaman } & \\
\text { 'Laporan' } & \text { untuk } \\
\text { melihat } & \text { daftar } \\
\text { calon pelamar } & \text { yang sudah } \\
\text { mengisi form } \\
\text { pendaftaran } \\
\text { dengan benar. }\end{array}$ & $\begin{array}{lr}\text { Halaman } & \text { dapat } \\
\text { dibuka dan } & \text { admin } \\
\text { dapat } & \text { melihat } \\
\text { daftar } & \text { calon } \\
\text { pelamar. } & \end{array}$ & $\mathrm{Ya}$ \\
\hline 15 & $\begin{array}{lr}\text { Membuka } & \\
\text { halaman } & \\
\text { 'Logout' } & \text { agar } \\
\text { admin } & \text { dapat } \\
\text { keluar } & \text { dari } \\
\text { halaman } & \text { khusus } \\
\text { admin. }\end{array}$ & \begin{tabular}{lr} 
Fungsi & logout \\
dapat & berfungsi \\
dengan & baik, \\
ketika & menu \\
logout di & klik, \\
maka & halaman \\
akan & otomatis \\
menuju & halaman \\
\multicolumn{2}{l}{ utama web. }
\end{tabular} & $\mathrm{Ya}$ \\
\hline
\end{tabular}

\section{Kesimpulan}

Berdasarkan perancangan sistem informasi company profile dan monitoring calon pelamar baru diatas, maka dapat ditarik kesimpulan sebagai berikut.

a. Dengan adanya usulan aplikasi ini, PT.Faros Bakti Utama Persada khususnya dalam perekrutan calon pelamar baru, menjadi lebih mudah dan efisien serta menghemat waktu dan biaya melalui sistem informasi company profile dan monitoring calon pelamar baru berbasis web.

b. Sistem informasi company profile dan monitoring calon pelamar baru ini juga dapat memudahkan masyarakat umum dalam mencari informasi mengenai 
perusahaan, seperti bidang industri, lokasi, serta informasi lowongan pekerjaan yang disebarkan perusahaan melalui web nya.

c. Bagi calon pelamar kerja, aplikasi ini juga sangat berguna, terutama dalam hal biaya. Calon pelamar kerja tidak lagi harus mengeluarkan biaya untuk berkas lamarannya karena aplikasi ini sudah menyediakan halaman untuk mengisi data diri dan mengupload berkas tambahan yang sudah di scan oleh calon pelamar.

d. Dengan adanya aplikasi ini, maka proses perekrutan calon pelamar menjadi lebih efisien dan menguntungkan bagi perusahaan sekaligus calon pelamar.

e. Interface dari aplikasi ini juga sangat mudah untuk dimengerti sehingga mempermudah pengguna dalam mengoperasikannya.

\section{Daftar Pustaka}

[1] L. Trisnawati and E. Syafrizal, "Rancangan Sistem Rekrutmen Karyawan Berbasis Web Pada Pt. Fast Food Indonesia Region Pekanbaru," J. Teknol. dan Sist. Inf. UNIVRAB, vol. 1, no. 1, pp. 25-30, 2016.

[2] M. Bagir, "Rancang Bangun Website Company Profile Pada Newton Vintage Store Surabaya," 2017.

[3] D. Maulana, "Perancangan Sistem Informasi Perekrutan Karyawan Pada PT.SMAP Indonesia Berbasis Web Programing," Teknol. Pelita Bangsa, vol. 7, no. 2, pp. 171-178, 2017.

[4] R. Ardianto and G. B. Sulistyo, "Perancangan Sistem Informasi Perekrutan Karyawan Pada PT Yogya Indah Sejahtera Yogyakarta," IJNSIndonesian J. Netw. Secur., vol. 9, no. 5, pp. 1-8, 2020.

[5] A. A. Rizky and I. Ramdhani, "Perancangan Sistem Informasi Perekrutan Karyawan Berbasis Web
Menggunakan PHP dan MySQL DI PT. Ria Indah Mandiri," J. Manaj. Inform., vol. 9, no. 1, pp. 49-57, 2019 , doi: 10.34010/jamika.v9i1.1651.

[6] N. Oktria Supatra and F. Masya, "Analisa Perancangan Sistem Informasi Perekrutan Karyawan Outsourcing Berbasis Web Pada Pt Bsi Pro," Jusibi - (Jurnal Sist. Inf. Dan E-Bisnis), vol. 2, no. 1, pp. 26557541, 2020.

[7] M. Susanti, "Perancangan Sistem Informasi Akademik Berbasis Web Pada Smk Pasar Minggu Jakarta," Informatika, vol. 3, no. 1, pp. 91-99, 2016.

[8] P. Palcomtech, "Rancang Bangun Website Company Profile Pada Pt . Parahyangan Dwi Karya," 2018.

[9] D. I. Cv, K. Informatika, L. S. Maulana, N. Hasti, and L. Y. Hastini, "Vol.15 No. 1," vol. 15 , no. 1, pp. 95110.

[10] T. Akhir, "PERANCANGAN WEBSITE COMPANY PROFILE LEMBAGA PENJAMIN MUTU PENDIDIKAN ( LPMP ) JAWA BARAT," 2021.

[11] W. K. H. Hqjlqh, W. V. E. Vr, P. D. Q. Pdfklqhv, W. Pdgh, L. W. Hdvlhu, and L. Belakang, "ANALISIS DAN PERANCANGAN SISTEM INFORMASI PENERIMAAN PESERTA DIDIK BARU BERBASIS WEBSITE PADA SMP NEGERI 2 MOJOSONGO Pendahuluan Landasan Teori \& Tinjauan Umum," vol. 14, no. 04, pp. 2-7, 2013.

[12] P. Y. B. Andalan, "Rancang Bangun Company Profile Berbasis Website Pada Smpn 39 Surabaya," 2018.

[13] S. Andrianto and H. Wijoyo, "Rancang Bangun Sistem Informasi Siswa Berbasis Web di Sekolah Minggu Buddha Vihara Dharmaloka Pekanbaru," TIN Terap. Inform. 
Nusant., vol. 1, no. 2, pp. 83-90, 2020.

[14] H. T. SIHOTANG, "Sistem Informasi Pengagendaan Surat Berbasis Web Pada Pengadilan Tinggi Medan," vol. 3, no. 1, pp. 6-9, 2019, doi: 10.31227/osf.io/bhj5q.

[15] I. Journal, "Perancangan Sistem Informasi Pendataan Siswa SMP Islam Swasta Darul Yatama Berbasis Web," vol. 4, no. 1, pp. 39-44, 2015.

[16] T. Dewanto and M. Ayunandya, "LKP : Rancang Bangun Company
Profile Berbasis Website pada SMPN 39 Surabaya," J. Ilm. SCROLL, vol. 3, no. 1, pp. 11-32, 2015.

[17] L. Setiyani, "Pengujian Sistem Informasi Inventory Pada Perusahaan Distributor Farmasi Menggunakan Metode Black Box Testing," Techno Xplore J. Ilmu Komput. dan Teknol. Inf., vol. 4, no. 1, pp. 1-9, 2019, doi: 10.36805/technoxplore.v4i1.539. 